DOI: $10.17805 /$ trudy.2019.1.10

\title{
КРОСС-КУЛЬТУРНЫЕ ОСОБЕННОСТИ ПРОФЕССИОНАЛЬНОЙ ДЕЯТЕЛЬНОСТИ ПРЕДПРИНИМАТЕЛЕЙ ВОСТОЧНОГО И ЗАПАДНОГО ТИПОВ
}

\author{
И. Р. Федоркова \\ Московский гуманитарный университет
}

\begin{abstract}
Аннотация: В статье рассмотрены особенности профессиональной деятельности предпринимателей восточного и западного типов. Охарактеризованы особенности этнокультур как основы для формирования бизнес-моделей. Выделены и описаны основные компоненты профессиональной деятельности восточных и западных предпринимателей.

По материалам научного доклада на конференции «Кросс-культурные и междисциплинарные исследования в истории психологии: результаты и перспективы» (Москва, 24-25 ноября 2018 г.), проведенной в рамках проекта № 18-513-18017, поддержанного РФФИ.
\end{abstract}

Ключевые слова: предпринимательство; Запад; Восток; западный тип; восточный тип; тип культуры; кросс-культурные особенности

\section{CROSS-CULTURAL PECULIARITIES OF THE PROFESSIONAL ACTIVITY OF BUSINESSMEN OF THE EASTERN AND WESTERN TYPES}

\author{
I. R. Fedorkova \\ Moscow University for the Humanities
}

\begin{abstract}
The article considers the peculiarities of the professional activity of businessmen of the eastern and western types. The author characterizes the peculiarities of ethnic cultures as the basis for the formation of business models. The main components of the professional activity of eastern and western businessmen are singled out and described.

The research is based on the materials of the scientific report at the conference "CrossCultural and Interdisciplinary Studies into the History of Psychology: Results and Prospects" (Moscow, 24-25 November 2018), held within the project No. 18-513-18017 supported by RFBR.
\end{abstract}

Keywords: entrepreneurship; West; East; western type; eastern type; type of culture; cross-cultural peculiarities

\footnotetext{
${ }^{1}$ Работа выполнена при поддержке гранта РФФИ № 18-013-01075 «История становления предпринимательства в России».

The study was financially supported by a RFBR grant No. 18-013-01075 "The History of the Formation of Entrepreneurship in Russia".
} 
Научные труды Московского гуманитарного университета 2019 № 1

Основу данной статьи составили результаты собственного диссертационного исследования (Федоркова, 2000), переработанные и дополненные в ходе последующего размышления над материалом.

В начале 90-х годов XX века, после распада Советского Союза, возникла необходимость перехода к новым методам хозяйствования. Собственная предпринимательская модель за долгие постреволюционные годы была прочно забыта, поэтому заимствование происходило с Запада (прежде всего из США), казавшегося тогда для многих россиян эталоном успешной жизни.

Психологи отмечали интересное явление, проявившееся в среде «новых русских» - предпринимателей начала 1990-х годов: бизнес налажен, дом - «полная чаша», а человеку не уютно, он испытывал беспокойство, тревогу и вынужден был обращаться за помощью к психологам-консультантам. Вероятно, этот феномен объяснялся происходящим нарушением в системе базовых ценностей на уровне архетипов.

Русский народ с древних времен отличался коллективистским мироощущением, привык жить в составе общины, которая регулировала жизнь своих членов: оказывала поддержку, применяла санкции. Самым страшным наказанием для крестьянина, например, было изгнание из общины. Например, при нарушение постановлений «мира» в период Трезвенного движения XIX века в первый раз виновный подвергался денежному штрафу 1 рубль или должен был очищать «от грязи и сору» улицы и площади, во второй раз - подвергался телесному наказанию - 10 ударов на открытой площади или должен был уплатить штраф 2 рубля серебром, в третий раз - штрафу 3 рубля серебром или наказанию 25 ударами розог с выдержкой семидневного ареста, а в четвертый раз «как пьяницу и распутной жизни человека» его удаляли из общины (Крестьянское движение... , 1963: 196). Это была крайняя мера, сродни смертной казни, ибо изгнанный из общины человек практически умирал для полноценной жизни в социуме. Вероятно, именно такое состояние испытывали начинающие предприниматели 90-х годов, которые отделились от значимого социального окружения, а новую «общину» еще не обрели.

К. Касьянова пишет, что «созидание порядка в области социального целого приносит самое большое удовольствие, приносит чувство своей нужности, значимости в этом мире... В этой сфере лежат основные, наиболее сильные наши ценности... Мы народ воистину коллективистский, мы можем существовать только вместе в социуме, который постоянно устраиваем, охорашиваем, волнуемся и переживаем за него, который, в свою очередь окружает нас теплом, вниманием, поддержкой» (Касьянова, 1994: 180).

Потребность жить в коллективе, как прежде в крестьянской общине, стимулировала и дореволюционное купечество к созданию в XVIII в. аналога 
крестьянской общины - Московского купеческого общества - задолго до основания официальных предпринимательских союзов в производственной сфере (XIXв.). В свою очередь, и названия сугубо профессиональных организаций в России - «Полное товарищество», «Товарищество на вере», «Акционерное товарищество», «Артельное товарищество» (понятия, употребляемые в качестве синонимов «артели» - «братство», «дружина», «община», «согласие», «братчина», «обчая», «стая», «ватага», «складчина») - отражают основные принципы их существования: партнерство, добровольное объединение, согласие, ответственность друг перед другом, сопричастность, соучастие.

Изучение истории отечественного предпринимательства позволяет сделать вывод о том, что утраченная после революции отечественная предпринимательская модель имела сходство с японской (восточной) и была противоположна по своему характеру американской (западной). Этот феномен определяется отличием восточного и западного типов культур, основанных в том числе на разных законах и принципах восточного и западного типов мышления (Федоркова, 2018: Электр. ресурс).

Японская и русская этнокультуры относятся к типу репрессивных, т. е. требующих от человека значительного самоограничения, репрессии своих личных целей в пользу глобальных культурных ценностей. Представители «репрессивных культур» отличаются терпеливостью и самоконтролем, преувеличенным сознанием роли социальных связей и общественных обязанностей, приверженностью к традициям. Данные особенности предполагают проявление таких личностных свойств как: консерватизм, любовь к порядку, преданность семейным устоям, уважение к религии предков, родителям, властям, повышенное внимание к чести имени и семьи. В отличие от русской и японской этнокультур американская не носит репрессивный характер, в ней ценность самоограничения невелика, а ценности активности, самореализации, новизны, динамичности преобладают. Как следствие, нет столь сильной зависимости от традиций, преувеличения значимости социальных связей и общественных обязанностей.

Для представителей русской и японской культур характерны ценностно-рациональные мотивы поведения, согласно которым социальное действие детерминировано убеждением в том, что определенная линия поведения ценна сама по себе, с точки зрения этической, эстетической, религиозной, независимо от ее результатов. Для представителей американской культуры характерны целерациональные мотивы поведения, которые предполагают существование ожиданий относительно поведения объектов внешней среды, с помощью этих ожиданий осознанно оцениваются и рассчитываются условия и средства для достижения цели. Таким образом, 
Научные труды Московского гуманитарного университета

2019 № 1

американские предприниматели скорее получат удовлетворение от реального достижения поставленной цели путем получения прибыли, а японские и отечественные - от осознания общественной пользы создаваемого продукта труда.

Подтверждением вышеизложенного может служить сравнительный анализ содержания мемуаров отечественных предпринимателей И. Д. Сытина, П. И. Щукина (Сытин, 1962; Щукин, 1911-1912), американского бизнесмена Дж. Рокфеллера (Рокфеллер, 1992) и японских предпринимателей А. Мориты, К. Татеиси (Морита, 1993; Татеиси, 1990).

Рокфеллер озаглавил свои мемуары «Искусство разбогатеть», тем самым, определив основную цель книги - научить молодых предпринимателей зарабатывать деньги. Очень часто на страницах его книги появляется слово «барыш», «прибыль», как основная оценка итогов деятельности ${ }^{1}$.

Работа известного книгоиздателя Сытина называется «Жизнь для книги»; объект, на который направлено основное внимание автора, - книга, как общественно-важный продукт, создание которого являлось смыслом жизни для И. Д. Сытина. Он значительно преобразовал книгопечатное дело в России: впервые стал издавать собрания сочинений отечественных писателей, иллюстрированные книги для детей и др. (Рууд, 1996).

Существенны различия и в самом стиле написания мемуаров. Дж. Рокфеллер основное внимание уделял освещению производственных вопросов: принципов, механизмов ведения дел, и меньше писал о людях. Для того чтобы рассказать о друге, он просит извинить его за частные отступления. Воспоминания И. Д. Сытина, П. И. Щукина, А. Мориты напротив, в основном повествуют о людях, они делятся с читателями уроками собственной жизни, в то время как описание производственной сферы носит эпизодический и подчиненный характер.

Совершая целерациональный акт, человек точно знает, какой результат будет получен. Совершая ценностно-рациональный акт, человек может верить или надеяться, но рассчитывать ни на что не должен, действуя по принципу: «Делай, как должно, и пусть будет, что будет». Ярким примером может служить деятельность И. Д. Сытина по изданию «Военной энциклопедии». Издатель, откликнувшись на призыв русских офицеров, считавших,

\footnotetext{
${ }^{1}$ Например, «Очистка керосина - очень легкий и простой процесс, а барыш первое время дело несло значительный» (Рокфеллер, 1992: 15); «Эта продажа оказалась для стальной компании делом очень выгодным, а мы, получив в уплату, большей частью, ее же паи, получили возможность быть участниками в их барышах» (там же: 51); «Ведь надо же кому-нибудь вести это дело для нас, а он, как и всякий другой, также хорошо может положить этот барыш в свой карман» (там же: 48); «Иной раз приходилось отказываться от надежды получить барыш в месте, где мы все уже подготовили» (там же: 57).
} 
что книг по военной тематике в России недостаточно, решил издавать на свои средства «Военную энциклопедию», планируя бесплатно отдавать книги в полковые библиотеки. За пять лет было издано 19 томов! Работа была положительно оценена царем и морским министром И. К. Григоровичем, но получила неодобрение со стороны военного министра В. А. Сухомлинова. «Пять лет труда пропали даром. Несколько миллионов рублей было брошено в печку, а мои мечты о создании в русских полках библиотечек прикладных знаний так и остались мечтами», — писал Сытин (Сытин, 1962: 105).

Подтверждение ценностно-рациональной модели поведения, мы находим и в книге японского предпринимателя, основателя фирмы Омрон, теоретика и философа менеджмента К. Татеиси (Татеиси, 1990), который предпочитаемым мотивом деятельности своего предприятия провозгласил работу во имя процветания общества на основе реализации корпоративной политики «предприятие-слуга общества». Автор обосновывает свою позицию оригинальным способом, посредством притчи о средневековых строителях замка, которым был задан вопрос: «Для чего вы работаете?» Один ответил: «Чтобы иметь пищу»; второй — «Чтобы обтесать камни для каменной стены», а третий ответил так: «Чтобы построить этот замечательный замок». Таким образом, первый рабочий, прежде всего, стремился к получению собственной выгоды, позиция второго является формально-нейтральной, а третий был нацелен на получение общественно-полезного продукта. В заключении Татеиси делает вывод о том, что «если имеется хоть малейший шанс на успех, всегда следует развивать сознание, определяемое третьим вариантом. Такое сознание дает служащим компании радость от работы, радость творчества, радость бытия. Работа превращается в служение искусству» (там же: 44).

Существует отличие между представителями Запада и Востока в способе принятия коллегиального решения и процедуре проведения дискуссий. Западные участники садятся за стол переговоров с уже сложившейся точкой зрения, в большинстве случаев ясно представляя окончательное решение и обсуждение вопроса сводится к противостоянию различных точек зрения. Восточные участники, усаживаясь за стол переговоров, как правило, не имеют готового ответа на рассматриваемый вопрос и совместно намечают будущий маршрут действий (Э. де Боно, 2010). Смысл поиска ответа на вопрос заключается в том, чтобы слушать друг друга. Потребность слушать друг друга стимулировала отечественных предпринимателей использовать даже учреждения формально-делового характера для неформальных встреч за чашкой чая, служивших порой основой для принятия важных решений.

Целерациональная модель американского предпринимательства проявлялась также и в сфере благотворительности. Во-первых, благотво- 
Научные труды Московского гуманитарного университета

2019 № 1

рительность еще не стала важной сферой деятельности в Америке XIX в. Рокфеллер только призывал американских предпринимателей: «Мы, американцы, уже достигли в жизни таких успехов, чтобы вправе требовать от наиболее видных своих сограждан больших пожертвований в пользу общественности» (Рокфеллер, 1992: 68) ${ }^{1}$. Во-вторых, в делах благотворительности, по его мнению, нужно заставить «говорить не столько сердце, сколько разум» и «научиться находить приятным тот род пожертвований, который влечет длительную благодарность» (там же: 69). Главная цель - прогресс цивилизации, а благотворительность, как проявление акта милосердия, вызывала у бизнесмена сомнение, он говорил: «Не думаю, что было бы полезно подавать нищим на улице милостыню» (там же: 88).

Размах благотворительной деятельности дореволюционных отечественных предпринимателей, в свою очередь, подтверждает ценностно-рациональную модель поведения. Они так же, как и западные коллеги, выделяли средства на предприятия, способствующие общественному прогрессу, например, открывали учебные заведения, создавали биржи (О пожертвовании денег на строительство биржи .... , 1818), учреждали публичную библиотеку с музеем наук и искусств (О сборе пожертвований на учреждение .... 1860) и др. Вместе с тем они жертвовали средства не столько по велению разума, сколько по велению сердца: на сооружение и ремонт храмов (Дело по отношению эстляндского губернатора ... , 1889-1892 гг.), памятников (Об открытии подписки .... , 1825), благотворительных гнорзаведений для вдов и сирот (Об изыскании способов ..., 1827); на благотворительные мероприятия в связи с окончанием войны (О пожертвовании купечеством 15000 рублей ... , 1809); на содержание военной богадельни (О пожертвовании московскими купцами 55000 рублей ... , 1857), на помощь арестантам в тюрьмах (О сборе пожертвований в пользу арестантов ..., 1859). Собирались пожертвования в пользу бедных жителей г. Самары (О сборе пожертвований в пользу бедных ... , 1850); для пострадавших от пожара в г. Кутаиси (0 сборе пожертвований в пользу пострадавших ... , 1861); для голодающих изза неурожая жителей Финляндии (О сборе пожертвований в пользу пострадавших от неурожая ... , 1862); приобреталось продовольствие для бедных жителей Москвы (О займе денег из капитала Андреевской богадельни ... , 1848) и т. д. Очевидно, что данные благотворительные акции не имели своей целью получение реальной выгоды и «длительной благодарности».

Профессиональный предпринимательский стиль в качестве компонен-

\footnotetext{
${ }^{1}$ В связи с этим трудно согласиться с С. К. Рощиным, который пишет о том, что концепция социальной ответственности бизнеса зародилась в 20-е гг., а получила наибольшее развитие в 70-е гг. XX в. в Америке (Рощин, 1995). Данная концепция существовала в российском предпринимательстве уже в XIX веке.
} 
тов включает в себя особенности организации деятельности предприятия и межличностных отношений. В связи с этим были реконструированы: доминирующая направленность, ценности и цели, формы поощрения работников, особенности взаимодействия предпринимателей с персоналом, партнерами, наставниками, а также степень их включенности в процесс производства. Предельно четко особенности отечественного предпринимательского стиля также выступают при сопоставлении с американским и японским.

Под направленностью в системе бизнеса мы понимаем ориентацию на дело или ориентацию на человека. Японский и российский стили характеризуются, прежде всего, ориентацией на человека, американский - на дело.

Основа японского и отечественного предпринимательства - принцип патриархальных традиций в организации жизнедеятельности предприятия, личная преданность делу. Работники японских компаний считают себя одной семьей, и японцы почти инстинктивно испытывают такие чувства, в то время как в США отношения руководства к рабочим и даже к руководителям низшего звена очень иерархичны и формальны (Морита, 1993).

Наличие патриархально-семейного типа взаимодействия между хозяином и работником в отечественном предпринимательстве подтверждается большим количеством примеров ${ }^{1}$. Внимательное и дружеское отношение хозяев к своим служащим входило, с точки зрения предпринимателей, в обязательный перечень достоинств настоящих купцов ${ }^{2}$. Патриархальный характер взаимоотношения купцов и их рабочих проявлялся также в том, что купцы считали своей обязанностью отвечать за нравственное состояние своих рабочих. Т. В. Прохоров лично занимался обучением взрослых рабочих чтению и письму. По выходным они собирались на фабрике для бесед или чтения книг духовно-нравственного содержания. Тематика бесед включала следующие вопросы: о честном труде; об удалении от пьянства; об опрятности в одежде, в пище и жилищах; о благопристойности поведения в доме и на улицах; о милосердии к домашним животным и др. К. В. Прохоров так объяснял свою по-

\footnotetext{
${ }^{1}$ И. Д. Сытин вспоминал: «Наши отношения с хозяином были патриархальными, жили мы по старинке. Я чувствовал себя не столько служащим, сколько членом семьи или воспитанником в доме воспитателя. Шарапов дарил мне шубу, костюмы, распекал за шалости» (Сытин, 1961: 26). Впоследствии Шарапов женил своего воспитанника и содействовал открытию им собственного дела.

${ }^{2}$ Н. К. Крестовников вспоминал: «При открытии Казанского стеаринового завода мы братски делили со своими сотрудниками труды, а в досужее время - и удовольствие. Мы составляли как бы одну семью. Обедали за общим столом, и, помнится, на меня возложена была обязанность метрдотеля, которую я исполнял, если не ошибаюсь, безупречно» (Кузьмичев, Петров, 1993: 48). С. И. Прохоров не только в лицо, но и поименно знал всех мастеров и рабочих (Прохоровы ... , 1996).
} 
Научные труды Московского гуманитарного университета 2019 № 1

зицию по данному вопросу: «Лучшее средство приготовлять мастеровых и честных людей, с детства иметь о них отеческое попечение, и через малолетних приучать к постоянству взрослых» (Прохоровы ..., 1996: 96).

Нередко хозяева выступали в роли арбитров в отношениях между рабочими. Как свидетельствуют книги полицейских донесений, Ефим Гучков женил и разводил рабочих по их просьбе и иногда даже судил их по уголовным делам (Гавлин, 1996).

Данный тип взаимодействия ярко контрастирует с американским, где даже отношения между отцом и сыном основывались на формальном деловом подходе. Рокфеллер пишет, что часто вовлекал отца в ссуды и тот приходил взыскать долг в момент наиболее острой нужды. «Я полагаю, что этот оригинальный воспитательный прием оказал мне, может быть, тоже немалую услугу, но я, признаюсь, в то время находил мало удовольствия в подобных испытаниях моих коммерческих способностей» (Рокфеллер, 1992: 11). В мемуарах А. Мориты видим противоположный подход отца к предпринимательскому начинаю сына: «В те дни мы часто брали деньги взаймы у моего отца. Он верил в нас и нашу новую компанию и не требовал возврата долгов» (Морита, 1993: 93). Морита в благодарность за поддержку выделил отцу долю в компании, сделав его одним из крупных акционеров.

Взаимоотношения между отцами и сыновьями в отечественном предпринимательстве также носили неформальный характер. Дети с ранних лет были включены в семейное дело, но поначалу выполняли черновую работу. Павел и Сергей Третьяковы, например, после домашних занятий с учителями исполняли обязанности «мальчиков в лавке», бегали по поручениям, выносили помои. Позже отец доверил им выполнение функций простых конторщиков (ведение торговых книг) и приказчиков (обслуживание покупателей) (Боткина, 1960). Многие сыновья до конца жизни отцов не отделялись от семейного дела, а после смерти продолжали его.

Сложившаяся ситуация отнюдь не означала несамостоятельности молодых предпринимателей, и как следствие развития у них потребительской позиции. В России богатство было индивидуальным, а не семейным, и наследодатель распоряжался средствами по своему усмотрению. Один богатый промышленник, например, не желая оставить все свое состояние сыну, завещал большие суммы церквам на колокола (Бурышкин, 1991). Наследник мог надеяться на наследство, но не в праве был его требовать. Таким образом, несмотря на поддержку и реальную помощь со стороны наставников, молодые купцы готовились к самостоятельной предпринимательской деятельности.

Купцы находили наставников не только в собственной профессиональной среде. Например, наставником и другом С. И. Мамонтова являлся 
Ф. В. Чижов - профессор математики, друживший с Н. В. Гоголем, И. С. Аксаковым, игравший заметную роль в общественной жизни страны. Под патронажем Чижова Мамонтов приобрел опыт финансиста-администратора в деле строительства и эксплуатации железных дорог. В свою очередь, $Ф$. В. Чижов участвовал вместе с С. И. Мамонтовым в строительстве Московско-Ярославской железной дороги в качестве его партнера по бизнесу.

Между наставниками и воспитанниками складывались неформальные, эмоционально-теплые, доверительные отношения. Например, Ф. В. Чижов, завещая наследство для создания сети технических училищ в своем родном городе Костроме и, проявляя особое доверие к Савве Мамонтову, назначил его своим душеприказчиком (Арензон, 1995).

Институт наставничества являлся неотъемлемой частью профессионального становления отечественных предпринимателей. Потребность в этом испытывали обе стороны: воспитанник стремился научиться, а наставник - передать опыт. Савва Морозов (первый) постигал ремесло ткача в заведении купца Кононова, а через 6 лет открыл собственное дело. Василий Прохоров был пристроен отцом к купцу-старообрядцу, занимавшемуся пивоварением, а в 1784 г. открыл собственное пивоваренное дело. Михаил Рябушинский, работая приказчиком у купца, проявил способности, заметив которые, хозяин доверил ему ведение дел и сдал лавку в пожизненную ренту. После смерти бывшего хозяина, Рябушинский выкупил лавку у его наследников (Иванов, 1996).

Купцы долго оставались под патронажем своих наставников, приобретая с их помощью не только опыт, но и реальную материальную поддержку. В детском и юношеском возрасте патронаж осуществлялся в форме обучения и контроля, в зрелом возрасте - в форме советов, помощи.

В отличие от отечественных американские предприниматели рано становились самостоятельными, вынуждены были надеяться только на себя, и, как следствие, усваивать целерациональную модель поведения. Маленькие Третьяковы работали в лавке своего отца, не имея еще самостоятельного заработка, а в это время восьмилетний Джон Рокфеллер выращивал и продавал индюшек, накапливая собственный капитал с детства ${ }^{1}$.

Важным принципом российского и японского бизнеса являлась личная преданность предприятию. Например, переход в другую организацию расценивается в Японии почти как предательство, что ярко контрастирует с

«Вся выручка шла в мою пользу, расходов не было никаких, они шли за счет матери и, таким образом, мое “состояние” возрастало. Его рост и изменения я тщательно, насколько умел, отмечал в своей бухгалтерии» (Рокфеллер, 1992: 3). 
высокой социальной мобильностью, существующей в американской культуре в целом (Сухарев В., Сухарев М., 1997) и в бизнесе в частности ${ }^{1}$. Факты, свидетельствующие о миграционных процессах в отечественном предпринимательстве, в исследованных источниках не обнаружены, напротив, выявлены примеры преданности работников своему предприятию. Например, в период кризиса, произошедшего на фабрике Прохоровых, многие служащие предпочли остаться на предприятии, получая минимальное жалованье; некоторые из них проработали на фабрике всю свою жизнь: В. И. Хвостов 70 лет, Н. В. Васильев - 67 лет, В. С. Пономарев, В. П. Колесников, А. А. Быков, С. В. Шахин - по 50 лет.

Для японского и российского профессиональных стилей присущи методы эмоционального воздействия: демонстрация уважения, признание заслуг, личное обращение за помощью к работникам². Знаменитая японская традиция рукопожатий руководителя с персоналом перед началом рабочего дня напоминает традиционные совместные перекуры на предприятии С. Т. Морозова, когда хозяин похлопывал рабочих по плечу и угощал папиросками из большого кожаного портсигара (Кузьмичев, Петров, 1993).

В Японии, как и в русском предпринимательстве, было принято доверять своим партнерам. Яркий пример тому - заключение сделки между

${ }^{1}$ А. Морита вспоминает: «У нас был управляющий районным отделом сбыта, который казался настолько перспективным, что я послал его в Токио в длительную командировку. Вернувшись в Штаты, он продолжал работать и радовать нас до тех пор, пока в один прекрасный день без всякого предупреждения пришел ко мне в кабинет и сказал: “Господин Морита, благодарю Вас за все, но я ухожу". Я не верил своим ушам. Но это не было шуткой. Один конкурент предложил ему оклад в два или три раза больше, и он принял предложение. Я понял, что это и есть американский образ действий. Через несколько месяцев я пошел на выставку электронных товаров, и там, в павильоне одного из наших конкурентов сидел этот предатель. Я думал, он будет избегать встречи со мной, но он бросился ко мне навстречу и непринужденно заговорил со мной, словно ему нечего было стыдиться, словно он не совершил по отношению ко мне бесчестный поступок. Потом я осознал, что с его точки зрения и с точки зрения американской системы его уход, хотя он имел информацию о нашем маркетинге и знал секреты нашей фирмы, не представлял собой ничего дурного» (Морита, 1993: 217).

${ }^{2}$ «Губонин такого обычая держался. Собьет артель в 500 человек и говорит: “Ребятушки, работа будет тяжелая и грязная. Я не хочу вас обманывать. Но только надеюсь на вас, на вас, как на каменную гору - не дадите меня в обиду”. Снимает картуз и поклониться им. "Спасибо. Работа от нас не убежит, успеем наработаться, давайте-ка сперва погуляем”. И тут примутся ребята гулять - недели две пьют без просыпу, а как отгуляют, тут только держись! По пояс в болоте стоят, в грязи копаются, а работают. У другого подрядчика давно бы сбежали. Кончат работу - Петр Ионович опять картузик снимет и поклонится: “Спасибо, молодцами работали”. И опять угощение» (из воспоминаний рабочего) (Московские легенды ... , 1993: 156-157). 
купцами в форме устного договора. В США отношения между бизнесменами носили более нормативный характер, сделки обязательно закреплялись юридическими документами. В связи с этим интересен пример из истории, иллюстрирующий разный подход американских и русских бизнесменов XIX в. в вопросе - доверять слову или документу.

Известный русский художник В. В. Верещагин взял написанные им картины из галереи П. М. Третьякова для выставки в США. Павел Михайлович не только бескорыстно предоставил картины, но и сам тщательно их упаковал с целью предохранения от повреждения при транспортировке. Привыкший иметь дело с П. М. Третьяковым, который говорил, что его слово «крепче документа», В. В. Верещагин не стал заключать письменный договор с американцами (как и П. М. Третьяков не заключил с художником никакого договора, просто дал свои картины во временное пользование). Воспользовавшись отсутствием письменного договора, организаторы выставки в Америке задержали картины еще на год, так как выставка пользовалась большим успехом у публики и приносила им большую прибыль. В. В. Верещагин, в свою очередь, не получив никакой финансовой выгоды, приобрел переживания и чувство вины перед Третьяковым, вследствие чего писал ему: «Я совсем не хозяин выставок моих в Америке. В противность формальному условию картины переданы American Art Association для выставок на целый год дольше, чем следовало, и с этими разбойниками - и истинными разбойниками - я ничего не мог поделать. Так попался я со сроком картин: в мое отсутствие, в противность формально мною данному полномочию, прикинули целый год к назначенному сроку, да и баста - не процесс же мне с ними начинать, смешить публику» (Верещагин, 1963: 85-86).

Отечественные предприниматели предпочитали «держать свое слово» даже в неблагоприятных ситуациях, старались оплатить долги, несмотря на нанесение ущерба собственному делу. Вознаграждением за такое поведение являлись взаимное доверие и благодарность партнеров ${ }^{1}$. Такова

На фабрике Гучковых случился пожар, но, чтобы не потерять доверие со стороны партнеров, Е. Ф. Гучков постарался выплатить все необходимые обещанные им суммы денег. В ответ было получено письмо от помещиков-овцеводов, являвшихся партнерами Гучковых: «Считаем долгом своим выразить перед Вами, что давно известная неизменность правил честности, которые всегда отличали Вашу торговлю, не изменились в неблагоприятное для Вас время. Вы не только не остановились в исполнении начатой с компаниею сделки, но, приняв сговоренную Вами шерсть, заплатили все деньги сполна, ранее даже определенного срока. Общее собрание акционеров свидетельствует Вам совершенную свою признательность и просит не сомневаться, что Компания сочтет за особое удовольствие продолжать на тех же основаниях взаимного доверия и обоюдных выгод дела с Вашим домом столь превосходно себя зарекомендовавшим»(1855 г.) (Очерк торговой ... , 1867: 12). Аналогичным образом Т. В. Про- 
Научные труды Московского гуманитарного университета 2019 № 1

была традиционная система взаимодействия, поэтому Я. В. Прохоров выражал недоумение в письме к новому партнеру (английской конторе), требующему предоплату за свою работу: «Что касается до верности заказа, то вы имеете от нас записку, а в подобных обстоятельствах нам доверяют, нашему честному слову и еще никто от нас не имел в оном неприятностей» (Прохоровы ..., 1996: 125).

По мнению А. Мориты, американские бизнесмены часто не доверят своим партнерам по бизнесу, «им приходится постоянно думать о своей защите от нападения сзади, вместо того, чтобы двигаться вперед и смотреть в будущее», поэтому в США в основном производят юристов, в то время как в Японии - инженеров (Морита, 1993: 241, 244).

Различия между американскими, японскими и российскими предпринимателями существовали и в степени непосредственной включенности их в процесс производства. В американском бизнесе появилось разделение функций между хозяином и управляющим организацией (менеджером). Владелец предприятия мог ничего не знать о технической стороне дела; более того, даже менеджеры часто обращались к консультантам. В то время как в Японии руководитель обязан знать все тонкости технологии производства, а дореволюционные российские предприниматели не только хорошо знали весь процесс, но сами обучали нанимаемых на фабрику работников ${ }^{1}$.

Потребность участвовать непосредственно в значимом деле проявлялась и в общественной деятельности отечественных предпринимателей .

Важной особенностью профессиональной деятельности предпринимателей являлась и доминирующая форма поощрения (относительно работников предприятий и самих предпринимателей). Для восточного типа доминирующими являются моральные формы поощрения, для западного материальная стимуляция имеет ведущее значение. Например, заработная плата японских рабочих ниже, чем у американских, но японские предприни-

хоров поступает в ситуации кризиса производства на фабрике. Он решил отдать все товары, фабричные здания и все имущество только бы расплатиться с долгами. Его выручил авторитет, которым он пользовался благодаря своей честности; кредиторы, которые могли бы получить прибыль от разорения Прохорова, отсрочили платежи на неопределенное время.

${ }^{1}$ Участник труппы Русской Частной Оперы вспоминал, что Савва Мамонтов работал так же много как все остальные члены труппы, он руководил всем, видел цель каждого спектакля, всего предприятия в целом и полностью контролировал положение в театре (Арензон, 1995). Аналогичные качества демонстрирует С. Т. Морозов, который чувствовал потребность самому быть активным участником общей работы по подготовке осветительных эффектов для сцены театра; он в рабочей блузе трудился в поте лица вместе со слесарями, электросварщиками, осветителями. Мастера, специалисты поражались его знаниям и работоспособности (Думова, 1992). 
матели, работая с людьми, поняли, что они трудятся не только ради денег, и «если вы хотите их стимулировать, деньги не самое эффективное средство. Чтобы стимулировать людей, надо сделать их членами семьи и обращаться с ними, как с ее уважаемыми членами» (Морита, 1993: 201). В России XIX в. по итогам проведения Всероссийской художественно-промышленной выставки награждались предприятия и их хозяева. Высшей наградой являлось получение права изображения на изделиях государственного герба. Затем в порядке убывания по значимости числятся следующие награды: золотая, серебряная, бронзовая медали; дипломы 1-го, 2-го и 3-го разрядов; почетный отзыв и денежная премия (Отчет о Всероссийской ..., 1884). Обращает на себя внимание тот факт, что денежная премия занимает последнее место в ряду, уступая первенство средствам морального поощрения.

Таким образом, особенности профессиональной деятельности предпринимателей восточного типа таковы: ценностное отношение к результатам своего труда; потребность принадлежать к определенной группе социума и решать бизнес-вопросы коллегиально; ориентация на человека; патриархально-семейный тип взаимоотношения между руководителями предприятий и работниками; личная преданность организации; доверительные, неформальные отношения с партнерами по бизнесу; непосредственная включенность предпринимателя во все стадии организации производства, потребность непосредственно участвовать в значимом деле, доминирование моральных форм поощрения над материальными.

Для профессиональной деятельности предпринимателей западного типа характеры следующие особенности: доминирование принципа индивидуализма как способа ведения дел; независимость, стремление к самореализации, личному успеху; рациональное отношение к результатам своей деятельности; ориентация на дело; формально-деловой тип взаимоотношений между руководителями предприятий и работниками; социальная мобильность; формально-деловые отношения с партнерами на строгой юридической основе; делегирование полномочий от предпринимателя к профессиональному управляющему - менеджеру; отсутствие стремления знать все тонкости производственного процесса; доминирование материальных форм поощрения над моральными.

Ведущий американский специалист в области менеджмента начала XX века Г. Эмерсон описывал два типа организаций - продуктивный, производительный («шиповник») и непродуктивный, непроизводительный («волчий тип»). Продуктивный тип организации, по его мнению, носит оборонительно-созидательный характер, где главная цель - созидание, а «шипы» используются только для защити от нападения из вне. Для таких организа- 
Научные труды Московского гуманитарного университета 2019 № 1

ций характерны: способность соотносить свою деятельность с потребностями социума и активно использовать помощь социума в ответ; принцип ответственности руководителя перед своими подчиненными и забота о них; компетентность руководителя и способность обучить сотрудника технологии производства; наличие воодушевляющих идеалов в организации. Непроизводительный тип, по мнению Эмерсона, создан для нападения на других с целью получения выгоды, личный произвол сверху и предъявление требований к подчиненным без предварительного их обучения.

Хочется отметить черты сходства производительного типа с описанным в статье восточным предпринимательским типом. Вместе с тем, Эмерсон критиковал наиболее успешных американских предпринимателей Э. Карнеджи, Д. Хилла, Д. Моргана и Д. Рокфеллера за стремление к прибыли и отсутствие созидательных идеалов. Он критиковал их также за способ управления, предполагающий сложную иерархию взаимоотношений, где каждый вышестоящий руководитель делегирует полномочия нижестоящим и освобождает себя при этом от всякой ответственности, в итоге всю ответственность перекладывают на рабочих (Эмерсон, 1992).

Возможно, с тех пор американский бизнес претерпел изменения, внедряя в орбиту своей деятельности человеко-ориентированные мотивы, но объективные критерии сохранения основных черт этого стиля мы можем наблюдать в настоящее время у нас в стране. Западная модель постепенно внедрилась в деловой мир нашего общества, и многие черты - формализация отношений, стремление к личному успеху как главный ориентир в деятельности, социальная мобильность - присущи в настоящий момент и современной российской бизнес-модели. В службе персонала Банка, в которой некоторое время довелось работать автору данной статьи, с настороженностью относились к сотрудникам, которые длительное время работали на одном предприятии, их избегали принимать на работу как «не креативных, пассивных, закостенелых, не стремящихся к карьерному росту».

Вместе с тем, можно отметить, что при приеме на работу в некоторые учреждения культурно-просветительского характера используются элементы подхода, характерные для традиционной отечественной модели: человек, отработавший длительное время в какой-либо организации воспринимается как «надежный, серьезный, ответственный». Таким образом, в современном российском обществе снова на повестке дня возникают вопросы, поставленные славянофилами и западниками еще в XIX в.

Сможет ли возродиться отечественная предпринимательская модель в нашей стране? Существуют ли в настоящее время в России предприятия, на которых используется купеческая, дореволюционная модель бизнеса? Эти вопросы заставляют размышлять и требуют дальнейших исследований. 


\section{СПИСОК ЛИТЕРАТУРЫ}

Арензон, Е. Р. (1995) Савва Мамонтов. М.: Русская книга. 240 с.

Боткина, А. П. (1960) Павел Михайлович Третьяков в жизни и искусстве. 2-ое изд. М. : Искусство. 355 с.

Бурышкин, П. А. (1991) Москва купеческая. М.: Высшая школа. 352 с.

Верещагин, В. В. (1963) Переписка В. В. Верещагина и П. М. Третьякова 1874-1898 гг. М. : Искусство. 138 с.

Гавлин, М. (1996) Российские Медичи. Портреты предпринимателей. М. : ТЕРРА ; Издательский дом «Экономическая газета». 319 с.

Думова, Н. Г. (1992) Московские меценаты. М. : Молодая гвардия. 338 с.

Иванов В. (1996) Зачем человеку деньги. Хроника жизни купеческой семьи Рябушинских. М.: ТЕРРА, Издательский дом «Экономическая газета». $447 \mathrm{c}$.

Касьянова, К. (1994) О русском национальном характере. М. : Институт национальной модели экономики. 367 с.

Крестьянское движение в России 1854-1861 гг. (1963) / под ред. С. Б. Окуня, К. В. Сивкова. М.: Издательство социально-экономической литературы. $882 \mathrm{c}$.

Кузьмичев А., Петров Р. (1993) Русские миллионщики. Семейные хроники. М.: «ВЛАДОС-МПГУ» ; фирма «Форос»; Школа-Пресс. 128 с.

Морита, А. (1993) Сделано в Японии. История фирмы «Сони». М. : Прогресс. 413 с.

Московские легенды, записанные Евгением Барановым (1993). М. : Литература и политика. 301 с.

Отчет о Всероссийской художественно-промышленной выставке 1882 г. в Москве. Отчет административный и исторический (1884) / под ред. В. П. Безобразова, действительного члена Императорской Академии наук. T. I. СПб. 227 с.

Очерк торговой и общественной деятельности Мануфактур Советника, Почетного гражданина и Кавалера, бывшего Московского Городского Головы Е. Ф. Гучкова (1867). СПб.: Тип. В. Веллинга. 19 с.

Прохоровы: материалы к истории Прохоровской Трехгорной мануфактуры и торгово-промышленной деятельности семьи Прохоровых. 17991915 гг. (1996) / сост. П. Н. Терентьев. М.: ТЕРРА, Издательский дом «Экономическая газета». 271 с.

Рокфеллер, Д. (1992) Искусство разбогатеть. Мемуары американского миллиардера. М. : Алфавит. 96 с.

Рощин, С. К. (1995) Предпринимательская деятельность: психология и идеология // Психологический журнал. Т. 16. № 1. С. 31-43.

Рууд, Ч. (1996) Русский предприниматель. Московский издатель. Иван 
Сытин. М.: ТЕРРА, Издательский дом «Экономическая газета». 303 с.

Сухарев, В. А., Сухарев, М. В. (1997) Психология народов и наций. Донецк: Сталкер. 400 c.

Сытин, И. Д. (1962) Жизнь для книги. М.: Издательство политической литературы. 279 с.

Татеиси, К. (1990) Вечный дух предпринимательства. Практическая философия бизнесмена. М. : Московский бизнес. 222 с.

Федоркова, И. Р. (2000) Психолого-историческая реконструкция Московского Купеческого Общества как субъекта предпринимательской активности : дис. ... канд. психол. наук. М.

Федоркова, И. Р. (2018) Изучение проблем мышления на кафедре общей психологии и истории психологии Московского гуманитарного университета [Электронный ресурс] // Научные труды Московского гуманитарного университета. № 1. URL: http://journals.mosgu.ru/trudy/article/view/680 (дата обращения: 12.01.2019). DOI: 0.17805/trudy.2018.1.5

Щукин, П. И. (1911-1912) Воспоминания : в 5 ч. М.: Синодальная типография.

Э. де Боно (2010). Шесть фигур мышления. СПб.: Питер. 112 с.

Эмерсон, Г. (1992) Двенадцать принципов производительности // Управление - это наука и искусство. М.: Республика. 349 с.

Дата поступления: 12.02.2019 2.

\section{Архивные документы}

Дело по отношению эстляндского губернатора о сборе пожертвований на сооружение православного соборного храма в г. Ревеле (1889-1892 гг.) // ЦИАМ., Ф.3., Оп.4., е.х.1028.

О займе денег из капитала Андреевской богадельни на покупку продовольствия бедным жителям г. Москвы, 1848 // ЦИАМ., Ф.2., Оп.1., е.х.4045.

О пожертвовании денег на строительство биржи около торговых рядов в Китай городе, 1818 // ЦИАМ., Ф.2., Оп.1., е.х.687.

О пожертвовании купечеством 15000 рублей на благотворительные дела в связи с окончанием войны с Швецией (1809 г.) // ЦИАМ., Ф.2., Оп.1., е.x.49.

О пожертвовании московскими купцами 55000 рублей в пользу военной богадельни, 1857 // ЦИАМ., Ф.2., Оп.1., е.х.4515.

О сборе пожертвований в пользу арестантов, содержащихся в Отделении военных арестантов, 1859 // ЦИАМ., Ф.2., Оп.1., е.х.6037.

О сборе пожертвований в пользу бедных жителей г. Самары, 1850 // ЦИАМ., Ф.2., Оп.1., е.х.4387. 
О сборе пожертвований в пользу пострадавших от пожара жителей г. Кутаиси, 1861 // ЦИАМ., Ф.2., Оп.1., е.х.6322.

0 сборе пожертвований в пользу пострадавших от неурожая жителей Финляндии, 1862 // ЦИАМ., Ф.2., Оп.1., е.х.6543.

О сборе пожертвований на учреждение в Москве публичной библиотеки с музеем наук и искусств, 1860 // ЦИАМ., Ф.2., Оп.1., е.х.6057.

Об изыскании способов для составления капитала на благотворительные заведения для вдов и сирот, 1827 // ЦИАМ., Ф.2., Оп.1., е.х.2283.

Федоркова Ирина Рудольфовна - кандидат психологических наук, доцент кафедры общей психологии и истории психологии Московского гуманитарного университета; заместитель директора по научно-просветительской работе Музея денег. Адрес: 111395, Россия, г. Москва, ул. Юности, д. 5. Тел.: +7 (499) 374-67-20. Эл. адрес: ira_kislova@mail.ru

Fedorkova Irina Rudolfovna, Candidate of Psychology, Associate Professor, Department of General Psychology and History of Psychology, Moscow University for the Humanities, Deputy Director for Scientific and Educational Activities, Money Museum. Postal address: 5, Yunosti St., Moscow, Russian Federation, 111395. Tel.: + 7 (499) 374-67-20. E-mail: ira_kislova@mail.ru

\section{Для цитирования:}

Федоркова И. Р. Кросс-культурные особенности профессиональной деятельности предпринимателей восточного и западного типов [Электронный ресурс] // Научные труды Московского гуманитарного университета. 2019. № 1. URL: http://journals.mosgu. ru/trudy/article/view/937 (дата обращения: дд.мм.гг.). DOI: 10.17805/trudy.2019.1.10 